\title{
Habermas and Zhuangzi against Liberal Eugenics
}

\author{
David Chai
}

\section{摘要}

是否有一種道家的基因增強倫理學? 考慮到時間差異, 道 家思想能容納這樣一種提問嗎? 就生命科技的持續進展而 言, 我們所面臨的存在論威脅是無比真實的。圍繞著自然與 人造的爭論曾經牢固地樹立在神學家與哲學家的頭腦之中; 然 而最近在自由優生學的喧㗊中上述爭論已然消失殆畫。這一運 動激起了幾位傑出人士的反對, 包括哲學家尤爾根・哈貝馬 斯。他們反對的立足點就是基因操控抹繁了人性本質與人造物 之間的差別。道家原則上贊同這一反對, 但卻是出於不同的理 由。本文將表明道家可以提供一種存在一宇宙論辯護——如莊 子在關於疾病與畸形的故事中所表明的一以加強哈具馬斯 從社會一政治視角出發的對自由優生學的批評。雖然沒有直 接提到自由優生學本身, 但與哈貝馬斯一樣, 這些故事表明人 類生命的開端根本説來是超出人類控制的, 而改變這一根基就 意味著重塑自我與自由的涵義。

David Chai, 香港中文大學哲學系助理教授, 中國香港。

《中外醫學哲學》XIV:2 (2016 年) : 頁 97-112。

(c) Copyright 2016 by Global Scholarly Publications. 


\section{【關鍵字】自由優生學 自然 人造 存在一宇宙論}

\section{Introduction}

If one were asked to present a Daoist ethics of human enhancement, how would one respond? Are we even justified in postulating such a (hypothetical) question given Daoism and biological engineering lie at opposite ends of the temporal spectrum? One is very easily tempted to answer no; however, in light of the rapid advancement of biotechnology and the very real ontological threat it poses, there are lessons to be learned from antiquity, especially when a tradition such as Daoism foreshadowed the morally corruptive power of technology. Indeed, the debate over the natural vs the artificial has been entrenched in the minds of men the world over since the beginning of recorded history. Swinging from theology, to philosophy, to science, this debate has most recently been swept up in the commotion over liberal eugenics. Liberal eugenics, as opposed to its authoritarian cousin, takes the onus of genetic manipulation out of the hands of the state and delegates it to individual parents. Despite its liberal nature, this movement has still managed to draw the ire of some prominent figures, the philosopher Jurgen Habermas among them, who claim that altering a child's genetic make-up destroys the line of distinction between the human (natural) and the manufactured (artificial). How interesting, then, that in Chinese antiquity, Daoism was already considering the implications of this destruction of self. We can thus say that Daoism, in principle, agrees with Habermas' rejection of liberal eugenics, though its reasons for doing so differ. The purpose of this paper is to establish wherein Daoism might enhance Habermas' discourse by offering an onto-cosmological layer of defense as seen in the stories on illness and malformation in the Zhuangzi. While not speaking to genetic manipulation directly, these stories nevertheless argue, as does Habermas, that humans have a beginning to life that is ultimately beyond their control and to alter this origin is to recast the meaning of selfhood in such a manner as to make it inhuman.

\section{Liberal Eugenics as a Philosophical Problem}

For those unfamiliar with liberal eugenics, the term was first used in mainstream philosophical discourse by Nicholas Agar (see Agar 1998; 2004); however, liberal eugenics as an ideal began in the early 1970s and has the following characteristics: be voluntary, individualistic, and state-neutral (see Fox 2007, 3-4). These attributes 
reflect a society that cherishes freedom and autonomy to the extent that everyone has the capacity to choose their own value system and create their own life-narrative. This is an important point because Habermas will use it as ammunition in his critique:

When one person makes an irreversible decision that deeply intervenes in another's organic disposition, the fundamental symmetry of responsibility that exists among free and equal persons is restricted. We have a fundamentally different kind of freedom toward the fate produced through the contingencies of our socialization than we would have toward the prenatal production of our genome (Habermas 2003, 14).

From the perspective of classical Chinese philosophy, Habermas' correlation between one's inborn nature and the moral nurturing one receives from society sounds closer to Confucianism than Daoism. However, upon closer inspection, the intonations of Daoism reveal themselves in the emphasis on differentiating the natural from the artificial. The restriction of freedom Habermas speaks of above, when seen in the context of Daoism, is not one of social integration but the inability to grasp one's onto-cosmological root in Dao. Herein lies the crux of the matter. Is genetic modification a barrier so different from the other obstacles we encounter in life that it reduces one to an ontologically second-class person? In other words, does this form of augmentation translate into pure inauthenticity or is it merely an altered state of naturalism? Habermas, citing Ronald Deworkin, is unequivocal in his response:

We distinguish between what nature, including evolution, has created... and what we, with the help of these genes, do in this world. In any case, this distinction results in a line being drawn between what we are and the way we deal, on our own account, with this heritage...We are afraid of the prospect of human beings designing other human beings, because this option implies shifting the line between chance and choice which is the basis of our value system (Habermas 2003, 28).

What is of primary importance for Habermas is the moral repercussion of genetically altering one's naturally given disposition to suit the desire(s) of an outside party, even when said party is one's parents. It appears, at least at this point in our analysis, that Habermas has no interest in the existential effect of said change; rather, it is the value system that is of overarching concern. The value system that informs the morality of Western society is, of course, inapplicable to 
that of Chinese antiquity when Daoism arose; however, the line of distinction between the inborn and externally nurtured was very much relevant to ancient Chinese methods of self-perfection and moral betterment. Indeed, the Daoists made it a central element of their philosophy: to be natural is to follow the way of Dao while to be nurtured is to follow the ways of men. The former is the path of ultimacy, one that leads to an understanding of the world unblemished by personal bias or selfishness; the latter is the path of disingenuousness, one that results in ever-greater division and injury.

Daoism, therefore, would view any form of external intervention - technological, medical, or ethical—as artificial and thus detrimental to one's well-being and connectedness to Dao, the source of all life in the universe. Whatever one's fate may bring, the Daoist would accept it on the grounds that all things change, and do so unceasingly, hence there can be no justification for resisting or altering the outcome. Nowhere is this more apparent than in the illness story from chapter six of the Zhuangzi. This story involves four friends, two of whom fall gravely ill but show no displeasure towards their condition. Although genetically predisposed to their deforming figures, Masters Yu and Lai carry on living as if their bodies were no different from those of healthy men. It is because they unquestioningly accept their allotment in life that they can live it to its utmost, free of the anxiety, despair, and trouble that plagues ordinary persons as they strive to ward-off signs of malaise or weakness. In this way, Daoism sees all naturally induced change as both unavoidable and beneficial as it paves the way for further, even more substantial change. A Daoist moral argument against liberal eugenics would hence be rooted in the principle that the human body is simply a temporary abode for the animating spirit of Dao; as it is given to us by Dao, we have no right to claim it as our own or treat it as we see fit. Dao gives us life when the time is right and takes it away when said time has expired; this is the unchallengeable nature of the universe, as Master Yu so eloquently states:

I obtained life when the time had arrived and will perish when such time moves on. If one complies with this time and follows along, neither sorrow nor joy can enter. This is what the ancients called "freeing the bonds of life" and yet there are those who cannot be freed because they are bonded to things. Moreover, nothing can out-strip Heaven and this is a long-known fact. What is there to dislike about my present state? ${ }^{1}$

(1) Translations of the Zhuangzi are my own unless stated otherwise. 
Master Yu's self-acceptance is not due to social conditioning but arises from his bond with Dao. Indeed, it is Master Yu that educates others regarding his condition, a point advocates of liberal eugenics would be hard pressed to support. Knowing their son would end up physically malformed, Masters Yu's parents, in the eyes of eugenicists, would have a moral responsibility to correct, indeed relieve, their son of his future suffering. Having done so, they would embark on his resocialization such that Master $\mathrm{Yu}$ would eventually stop seeing himself as abnormal. There is thus no clear line between the natural and the artificial, a point Habermas rejects: "In order to justify the normative admissibility of these interventions, advocates of liberal eugenics compare the genetic modification of hereditary factors to the modification of attitudes and expectations taking place in the course of socialization... [arguing] there is no great difference between eugenics and education" (Habermas 2003, 49). To put things more succinctly, Habermas' objection lies in the fact that "the programmed person cannot see the programmer's intention, reaching through the genome, as a contingent circumstance restricting her scope of action" (Habermas 2003, 60).

The connection between Habermas' objection and the above-cited passage from the Zhuangzi lies in their common belief that natural life is devoid of any preprogramed history and as such, there can be no questioning of its source. If, however, our life history has been set by a genetic designer, then the path our life ends up taking is no longer natural but derived through artificial means. What is more, given the creator of the enhanced human is herself human, the subject in question will forever feel subservient to them, losing any sense of personal freedom they would otherwise enjoy if their creator were ephemeral. This loss of freedom is, for Habermas, social in scope whereas for Daoism, it is cosmological; without the freedom to design her life history, the genetically modified person is enslaved to the social proclivities of humanity; similarly, being born without an untouched inborn nature is, for Daoism, to exist in violation of the natural laws of the universe.

This is why Michael Sandel takes the trouble of pointing out that "an ethic of autonomy and equality cannot explain what is wrong with eugenics" (Sandel 2007, 81); Habermas, he writes, needs to provide something more, which he does:

Habermas is onto something important, I think, when he asserts a "connection between the contingency of a life's beginning that is not at our disposal and the freedom to give one's life an ethical shape.” For him, this connection matters because it explains why a genetically designed child is 
beholden and subordinate to another person (the designing parent) in a way that a child born of a contingent, impersonal beginning is not. [The drive to]... master the mystery of birth diminishes the designing parent and corrupts parenting as a social practice governed by norms of unconditional love (Sandel 2007, 82-83).

To put Sandel's affirmation of Habermas' claim that creation needs a creator not at the disposal of humans into perspective, we can return to the Zhuangzi's account of the sick friends, picking up where Master Yu last spoke. When asked if he resents his situation, Yu's reply is no. Having lived his entire life perfectly at ease with the changes taking place in his body, Master Yu has not sought out a cure for his ailments but is of the opinion that they are simply manifestations of the transformative power of the universe's primal elements: Yin and Yang. That his body has reacted to the mixing of Yin and Yang in such a negative way is no cause for alarm however; rather, it speaks to his higher understanding of the way the world operates and its dependency on Dao. Since his fate is to become as such, on what grounds is Master Yu to object? As it falls upon Dao to induce change in the world, who are we to question why? It is better to go along with Dao's spontaneity and end our quest to apply human standards to what is immeasurable. Genetic enhancement is hence illogical in that no matter how ingenious and well prepared we think we are, the natural forces of creation and destruction will always eclipse us. In the words of Habermas, "eugenic interventions aiming at enhancement reduce ethical freedom insofar as they tie down the person concerned to rejected, but irreversible intentions of third parties, barring him from the spontaneous self-perception of being the undivided author of his own life (Habermas 2003, 63).

When Habermas writes the subject of eugenic intervention can no longer be the author of her own life history, the loss of spontaneous creativity is not ontologically induced; rather, it is the result of being morally stigmatized and derided such that it "changes the overall structure of our moral experience" (Habermas 2003, 28). This dependency on moral justification as the yardstick for measuring the quality of human existence is also found in Confucianism and is why Daoism sought to transcend human ethics by tethering it to the ultimate, non-human virtue of Dao. By adopting Dao as the standard-bearer by which human endeavors are judged, the social, moral, and political frameworks used to guide our lives fall by the wayside, supplanted by the all-encompassing, non-judgmental perspective of Dao. We can see this in the second of our two stories on illness from chapter six of the Zhuangzi. This story involves Masters Li and Lai, the latter of whom is 
on his deathbed. When asked if he resents being in such an unpleasant state of health, he replies:

Children follow their parents and do whatever they are told: East, West, South, and North. As for Yin and Yang, how much more are they to man than either parent can be! Having brought me to the brink of death, should I refuse to follow, how awkward would that be! What fault is it of theirs? The Great Clod burdens me with form, labors me with life, eases me in old age, and rests me in death. If I think well of my life, I must also think well of my death.

The equalization of life and death is thus the Daoist way of circumventing the need to choose between the desirable and the undesirable. Such a solution is one Habermas cannot employ because his ethical language is not equipped to regard eugenics cosmologically. What is more, when Habermas criticizes liberal eugenics for rendering the subject "blindly dependent on the non-revisable decision of another person, without any opportunity to establish the symmetrical responsibility required if one is to enter into a retroactive ethical self-reflection as a process among peers" (Habermas 2003, 14), he leaves himself open to attack, as Sandel's remark illustrated. Indeed, there are a number of scholars not content with Habermas' critique of liberal eugenics, the most acknowledged of whom is Elizabeth Fenton.

\section{Defending the Anti-Eugenic Stance}

Fenton's disagreement with Habermas is premised on the latter's four primary arguments: liberal eugenics threatens the foundations of the human moral community; it profoundly alters relationships in said community due to the shift from natural to manufactured creation; such artificiality undermines the subject's moral equality; and finally, it undermines the subject's freedom and autonomy (Fenton 2006, 36). As we have been intimating throughout this paper, Habermas believes that human nature contains within it a core that defines us as such, making it off-limits to any kind of scientific alteration. To put it more succinctly, Habermas' worry over human nature is not pushed by existential concerns, or onto-cosmological ones as we see in Daoism; rather, what makes Habermas apprehensive are the moral implications of genetic enhancement and how this, in turn, bears upon our freedom as autonomous individuals living in social communities. The word autonomy is important in that Habermas questions whether liberal eugenics has the capacity to grant humans the ability to write our own life histories if we are simultaneously authoring those of others, or 
have had our own authored for us. This, he says, is an internal inconsistency: "The argument rests entirely on a dubious parallel, which itself presupposes a leveling out of the difference between the grown and the made, the subjective and the objective...[in that]...a person "has" or "possesses" her body only through "being" this body in proceeding with her life (Habermas 2003, 50). But is living one's life via the body enough to declare authorship of our life history? For Daoism, it is not.

The question that remains, however, is this: Is our body even ours to begin with? We saw in the two passages from the Zhuangzi reasons why it may not be and here is another, taken from chapter five of the text:

Hui Shi said to Zhuangzi: Can man be without feelings? Zhuangzi answered, yes. Hui Shi then asked: If a man lacks feelings, how can he be called a man? Zhuangzi replied: Dao provided him with a face and Heaven provided him with a form, in what way is he not a man? [What is more, such a man]...does not allow likes or dislikes to enter [his heart-mind] and cause him harm. Yet, here you are treating your spirit as if it were a stranger; you exhaust your qi, leaning on a tree sighing or slumped at your desk asleep. Heaven provided you with a body and yet you use it to rant about hard and white!

Zhuangzi's view is that our physical selves are not ours - they are not even bestowed to us by our parents-hence any changes that occur to our body are beyond our control. If the Daoists of ancient China had access to the kind of technology necessary for genetic manipulation, they would reject it on the grounds that to alter the nature of what does not, cosmologically, belong to us is to engage in selfish and short-sighted behavior. To hold ourselves above the laws of nature, to resist the inevitable, is to be blind to the interconnectedness of everything in the universe. Indeed, the unity of the universe is premised upon the mutual co-dependency of all things and their changes, and to erase any trace of this out of fear or misplaced arrogance is to cause irreparable harm to the world and ourselves. Returning to Habermas, the technology used in eugenics is dangerous because it eradicates the moral bond supporting the parent-child relationship, thereby "blurring the intuitive distinction between the grown and the made, the subjective and the objective-with repercussions reaching as far as the self-reference of the person to her bodily existence” (Habermas 2003, 47). 
As in Daoism, where humanity must work to maintain, or regain when lost, the connection to Dao, so too does Habermas feel humans are endowed with a core of being that is inalienably unique and in need of protecting. As Fenton rightly notes, Habermas' goal is "to achieve active self-reflection as a species: once the species reflects on what makes it possible to live as we do now...it will understand that radical genetic technologies are inconsistent with this basic aspect of being human, and it will therefore reject them" (Fenton 2006, 37). The separation of natural and manufactured is critical for Habermas, and Daoism too, in that without the former, the latter will dominate the world in such a way that people will view others, or the natural world in the case of Daoism, as but mere instruments to be used and discarded. In other words, the child of genetic engineering will not be treated as if she were entering into a subject-subject relationship; rather, in knowing they were manufactured, albeit genetically, society will view them as morally deprived objects that lack the freedom to make life-altering decisions. Fenton's first objection thus lies with Habermas' theory that human nature is unalterable and knowable: for her, human nature is alterable and it is not predefined. The reason, she argues, is that even if there are "certain natural features of humans that are found universally, it does not follow that these capacities are fixed, nor that they exhaust the inventory of "truly human" characteristics, nor that they cannot be improved upon, nor that they should be elevated to a moral status that entitles them to protection" (Fenton 2006, 39).

If, as Daoism claims, Dao spontaneously provides the conditions for the things of the world to come-into-being, then that kernel of potency - that spark of existence-is already set as their inborn nature. Fenton might be right to disagree with Habermas' social morality but she is not so when we add cosmology to the equation. We must remember that liberal eugenicists are empowering parents, as creators in their own right, with the ability to alter the inborn nature of their future offspring; once the keys to creation are laid bare, any untoward consequences as it relates to our ties with the ultimate creator, cannot be taken back. Even the use of biomedical implants and exoskeletons to sustain or enhance one's quality of life are ruled out insofar as "instrumentalization of human nature [changes our]...self-understanding [such that it is] no longer consistent with the normative self-understanding of persons who live in the mode of self-determination and responsible action" (Habermas 2003, 42). Daoism would dismiss intervention of this kind too because technology should not replace the innate capacity for humans (indeed, all living things) to physiologically perform certain actions. The story 
of the well sweep in chapter twelve of the Zhuangzi is a perfect illustration of this:

Where there are machines, there will also be machine worries; where there are machine worries, there will also be machine heart-minds. With a machine heart-mind within you, that which was pure and simple is now despoiled; without that which is pure and simple, the spirit will know nothing of rest. When the spirit knows nothing of rest, Dao will no longer support you.

The above passage ties in nicely with Fenton's second criticism of Habermas' belief that liberal eugenics changes the "ethical self-understanding of the species, which is shared by all moral persons" (Habermas 2003, 40). According to Fenton, “even if we agree with Habermas that human dignity is best understood in terms of a state associated with membership in the intersubjective moral community, we can deny that there is a moral dimension to any definition of what it is to be human that follows from this view" (Fenton 2006, 39). Moving on, Fenton's third argument is that Habermas' concern that liberal eugenics alters the essence of human relationships is "overblown" (Ibid). To be specific, eugenic children will feel obliged to look upon their parents as their designer and not as their moral equal. According to Fenton, however, the parent-child relationship is by definition one of inequality; children who have been genetically manipulated will hence be no worse off than those born untouched. What Habermas wants to show, however, is how human enhancement results in a fundamentally unstable society due to the asymmetrical relationships generated through manufactured children. Fenton, for her part, is arguing such reasoning is too weak to establish any violation of human nature.

This brings us to Fenton's fourth and fifth criticisms of Habermas: the former involves the debate over the natural versus the artificial, while the latter concerns the autonomy and freedom of genetically engineered children (see Fenton 2006, 40). We can refute Fenton with the following: "Irrespective of how far genetic programming could actually go in fixing properties, dispositions, and skills, as well as in determining the behavior of the future person, post factum knowledge of this circumstance may intervene in the self-relation of the person, the relation to her bodily or mental existence (Habermas 2003, 53). When Fenton argues that all human behavior, and the education required to learn it, can be taken as artificial, she is misconstruing Habermas' statement due to her overlooking the underlying role of temporality. The moral implications of "dedifferentiating" (see 
Habermas 2003, 46) the organic from the manufactured are only felt in the future self of the eugenic child. As they are genetically programmed by their parents, children who are biologically bound to their creators lack the capacity for spontaneous change, be it physically or psychologically. In other words, these children are denied the chance to grow and adapt to their evolving selfhood, not because their less-than-perfect selves will be a source of personal discomfort or pain; rather, their transmutation into an undesirable object is deemed an inconvenience and point of contention for their parents. In other words, the child is blamed for a life that is not of her own devising.

Recall in Zhuangzi's story of Master Yu how the inborn nature of things is not self-determined but bestowed to them by Dao, thus forming an onto-cosmological community forever in unity with Dao. Master Yu's cosmic fatalism thus prohibits him from considering the kind of claims made by Fenton. For a parent in ancient China to consider biologically stripping or enhancing specific traits of their yet-to-be-born child would be unconscionable. Such being the case, Master Yu says, "neither sorrow nor joy can enter" and this is known as "freeing the bonds of life." We are bonded to a false sense of personhood, one wherein we not only claim ownership of our own body but of those over whom we lord. Parents who obsess over the future state of their children are thus enslaved to an egoism unlike any other. Rather than allow their child, despite their potential handicap, to explore the world as it presents itself to them through unfiltered glasses, parents in favor of liberal eugenics would take it upon themselves to pre-judge and determine what is in the best interest of the child without prior consultation. They are not, in the eyes of Daoism, adhering to the natural order of things but seeking to enforce a human-centric understanding where none is needed. Perfectibility lies not with uniformity but variation, lies not with conformity but creativity.

Part of what makes life special is the variety of its creations and part of what makes the variety of species special is the mystery of creation. One may argue that evolution accounts for the former and a god-like entity the latter, or one may argue all theories involving creation are but hypothetical estimations. To declare that science possesses all the answers we seek is no better a solution in that science is a human phenomenon and as such, its outcomes are verifiable by humans alone. The natural world relies on and preserves the mystery of life and death without resorting to any artificial models or systems of measurement. We, therefore, Habermas writes "experience our own freedom with reference to something which, by its very nature, is not at our disposal" (Habermas 2003, 58). This elusive key to life is precisely what liberal eugenics is trying to expose. 
Calling upon Daoism to supplement the argument of Habermas is not to lend his anti-eugenic stance an air of religiosity by attesting to the sanctity of life; rather, the Daoist notion that our lives are intertwined with Dao instills in us an existential appreciation for the life-world we create in the course of our living. What the stories on illness in the Zhuangzi illustrate is that one can live a happy life despite being physically imperfect; so long as we remove the element of guilt and self-doubt, there is no reason why persons such as Masters Yu and Lai will be incapable of living a meaningful life. Contrarily, someone who is "the sole product of a suffered socialization fate would see his "self" slip away in the stream of constellations, relations, and relevancies imposed upon the formation process" (Habermas 2003, 59-60). Against Habermas' preservation of the body as a morally socialized being, Zhuangzi entreats us to relinquish our corporeal selves so as to free our inner non-self. Without an objective self to worry about, persons who are guided by the non-self of Dao become immune to the trials and tribulations of life; they enjoy a freedom unmatched in the human world, a freedom rooted in the enjoyment of being one with Dao. What is more, as Dao is ultimate reality and nothing is left untouched by its creative possibilities, for humans to attempt to preempt its spontaneous outcome is surely an impossible feat. Best to let nature take its course, as the saying goes, and adapt accordingly.

\section{Eugenics and Staving-Off Death}

We have thus far spoken of liberal eugenics in the context of personhood and freedom and why both Habermas and Zhuangzi reject it for turning what is inherently natural into something that is utterly artificial. Our discussion has also been forward-looking, that is, addressing potential problems or introducing preferential characteristics into a child before they are born. What we have yet to do is take a retroactive look at eugenics and the role it might play at the end of one's life to stave-off death. As I have already given a phenomenological account of Zhuangzi's philosophy of death (see Chai 2016), for the remainder of this paper I shall discuss its moral import, doing so by way of the four Masters mentioned above.

Let us recall Master Yu's reply when asked if he resents his ailing health: "I obtained life when the time had arrived and will perish when such time moves on. If one complies with this time and follows along, neither sorrow nor joy can enter. This is what the ancients called "freeing the bonds of life."” We can offer three interpretations of this passage as it pertains to eugenics and death. First and foremost is the equalization of life and death via the transformational power of Dao. 
Given life and death are complimentary modes of existence and that each continuously effects the other in ways too subtle for us to experience, declaring one morally preferable and the other abhorrent is to erroneously believe we have control over either of them. In the eyes of Daoism, life and death are morally neutral and should not be intertwined with the human emotional condition. One may, of course, consider life and death from an existential perspective, but to stave-off death through genetic means is morally irrational for the Daoist insofar as it is the only inevitable outcome common to all things throughout the universe. This inevitable commonality is so, not because we humans claim it to be as such, but because death unites the things of the world via their temporal returning to Dao. Master Yu's explicit reference to temporality thus conveys how cosmological oneness is in fact a resonating of the virtue of Dao through the alternation of Yin and Yang forces. Eugenics thus seeks to not only bypass the natural processes of growth and decay but rewrite the role of time and how it comes to bear on life and death. It is for this reason that Daoism would argue any eugenic prolongation of life will only increase the speed with which death takes hold; tinkering with the clock of life only speeds-up the moment of its demise.

Our second observation has to do with the belief that modern medical science is able to make life all the more treasurable as it cures/treats previously incurable/untreatable illnesses. Against Habermas' view that the moral relations we create as members of a social community override the needs of individual parents when it comes to the well-being of their children, Daoists such as Zhuangzi turn to the notion of fate to explain the daily ebb and flow of life. Indeed, life and death themselves are but an arising and receding of Dao's creative potential. This naturalistic approach is morally benign, having no ties to a divine creator or spiritual animator. Such being the case, Daoism accepts the path taken by life and death at face value. We can no more read into them signs of goodness than we can wrongdoing; both are thus equally treasurable in that both are natural, spontaneous emanations of Dao. Dao's timelessness hence lends our inborn nature an air of transcendence that belies the finitude of our corporeal selves.

The third point relates to the expression "freeing the bonds of life," which itself can be broken down into two components: freedom and attachment to life. Chapter 29 of the Zhuangzi lists six evils that plague the minds of common men: disorder, suffering, disease, shame, worry, and terror. These six are the result of being bonded to things instead of forgetting oneself in Dao. There is freedom to be had in self-forgetting and when one attains it by conjoining with Dao, all forms of physical and psychological ailment vanishes. To be free from the bonds of life is to be free from viewing life as different from death, 
free from the need to over-protect life in the face of death's impending arrival. Should we follow the Daoist approach and equalize life and death, one will no longer feel compelled to venerate life whilst abhorring death; they are merely two temporal variants of Yin and Yang's circularity. If eugenicists believe that human enhancement is morally justifiable because it can alleviate the subject of future pain and suffering, or give them an edge over others by artificially boosting specific skills/talents, the Daoist would counter this claim by saying they are still fixated on life, and a very narrow understanding of it at that; they are too shackled by onto-epistemological blindness to see the co-dependency of opposites. The solution is not to emphasize the differences between things but their sameness, an axis of oneness around which all living things turn. Freeing ourselves of the need for self-modification is thus to free others from their need to emulate all that is artificial and against the way of Dao.

Whereas Zhuangzi's account of human finitude is shaped by the constancy of Dao, Habermas draws a correlation between our existence and moral standing in the world:

Since we can have no objective knowledge of values beyond moral insight, and since a first person perspective is inscribed in all of our ethical knowledge, we overtax the finite constitution of the human spirit by expecting that we can determine which sort of genetic inheritance will be "the best" for the lives of our children (Habermas 2003, 90).

The moral dilemma is a two-pronged one: to respect the finitude of the child and let nature take its course, or resort to an intervention such that the child's finitude is disregarded in order to benefit her family or society at large. In either case, proceeding with or refraining from taking action signifies a moral stance that is bound to find both support and condemnation. This is why Habermas argues that individuals must be allowed to author their own life histories. If each of us can look upon our finite being existentially, we can free ourselves of the need to even consider life enhancement or termination as subject to moral qualification. The result of giving life and death a Daoist aura is that we are no longer compelled to choose between acting and taking no action, but can practice the art of letting-be. This is the moral breakthrough seen in Master Lai's response to Master Li: "The Great Clod burdens me with form, labors me with life, eases me in old age, and rests me in death. If I think well of my life, I must also think well of my death.” In the face of death, moral equanimity is the best solution as it lets life attain self-completion in a manner wholly befitting the subject in question. 
The ethical argument of liberal eugenics in terms of the question of human finitude is hence ultimately self-defeating for the simple reason it cannot see past humanity's own humaneness. It cannot look at the issue of human change and transformation, whether for better or worse, from outside the realm of human existence and so it must resort to lines of argumentation that justify its very existence. Liberal eugenics, therefore, pushes the agenda of saving humanity from itself because of the perceived threat of finitude. The existential threat of our own demise, they hold, can be extinguished through physical reconstruction and reformation. Instead of accepting the fact that the mystery of life lies with a source beyond our comprehension, eugenicists strive to turn the inevitable into the predictable, and what is predictable can, in turn, be manipulated. This does not, however, change the fact that our life and death follow an unscripted path, no matter how much we try to influence the events effecting them. Taking a naturalistic approach and leaving each to its own devices, as Daoism advises, proves the best way to relieve ourselves of the fear beclouding our understanding of existence and personhood, such that we can get on with enjoying life as we are anatomically meant to do.

\section{Conclusion}

Pitting a modern movement such as liberal eugenics against an ancient tradition in the form of Chinese Daoism might, at first glance, seem like an odd choice. The former argues that parents have the inalienable right to ensure the best quality of life possible for their offspring while the latter subscribes to the belief that all life in the universe is borne of the mysterious workings of Dao and cannot be dissected or disseminated as such. It is on this point - that the origin of life lies with an ineffable source whose creational power leaves humanity with an unalterable core of being-that Daoism and Habermas share common ground. Indeed, the rest of their program have nothing in common but when brought together to protect the essence of human existence from technological incursion, they present an impenetrable front. As bioengineering becomes ever more advanced, achieving ever-greater breakthroughs, we as a species should take pause and reflect upon the nature, as opposed to the value, of human existence. If this necessitates we return to the past for insight and guidance, should we not do so willingly? 


\section{參考文獻}

Agar, Nicholas. “Liberal Eugenics,” Public Affairs Quarterly, 12:2 (1998), pp. 137-153.

. Liberal Eugenics: In Defense of Human Enhancement. Oxford: Blackwell Publishing Ltd, 2004.

Chai, David. “On Pillowing One’s Skull: Zhuangzi and Heidegger on Death,” Frontiers of Philosophy in China, 11:3 (2016), pp. 483-500.

Fenton, Elizabeth. "Liberal Eugenics and Human Nature: Against Habermas," The Hastings Center Report, 36:6 (2006), pp. 35-42.

Fox, Dov. “The Illiberality of 'liberal eugenics'," Ratio (New Series) 20:1 (2007), pp. 1-25.

Habermas, Jurgen. The Future of Human Nature. Cambridge: Polity Press, 2003.

Sandel, Michael. The Case against Perfection: Ethics in the Age of Genetic Engineering. Cambridge: Harvard University Press, 2007.

Zhuangzi. Nanhua Zhenjing (True Classic of Zhuangzi) in Daozang (Daoist Canon), 36 vols. Shanghai: Shanghai Bookstore Publishing House, 1988. 